$$
\begin{aligned}
& \text { SK } \\
& 361 \\
& W 67
\end{aligned}
$$




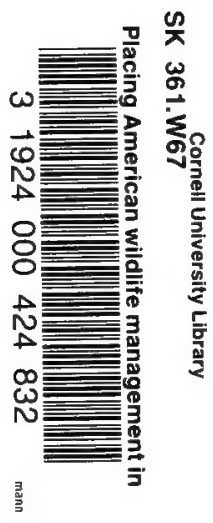




\section{PLACING AMERICAN \\ WILDLIFE MANAGEMENT \\ IN PERSPECTIVE}

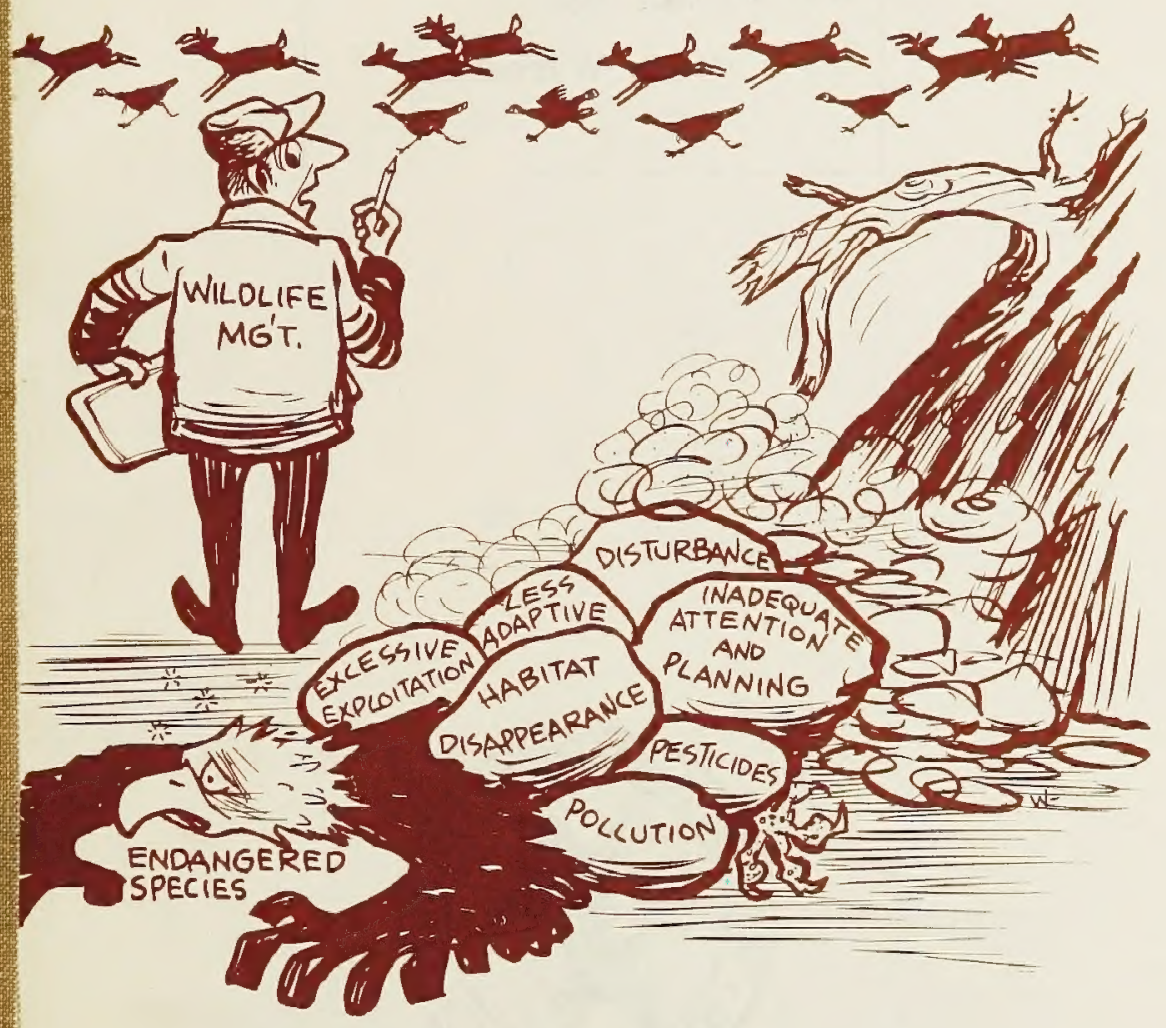



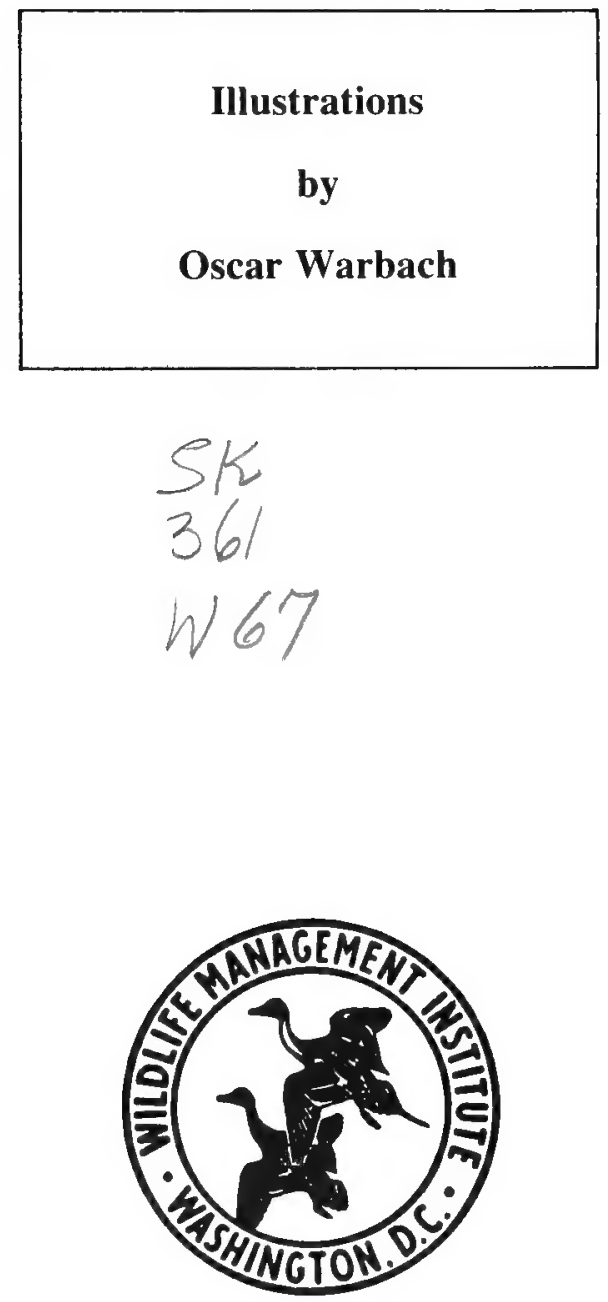

Published by

Wildlife Management Institute

1000 Vermont Avenue, N.W.

709 Wire Building

Washington, D.C. 20005 


\section{The Need for Management}

Writers and photographers have known for a long time that the plight of a wild animal struggling for survival makes a good story. Today, TV and illustrated magazines bring the problems of endangered species sometimes with calculated shock effect - into the American home.

Much of this publicity has been constructive. It has aroused needed public support for efforts to save animals threatened with extinction at home and around the globe. Congress, as a result, has approved progressively stronger programs to aid wildlife species in difficulty. And the United States has taken leadership in developing a world treaty that commits all nations signing it to protect threatened and endangered animal populations.

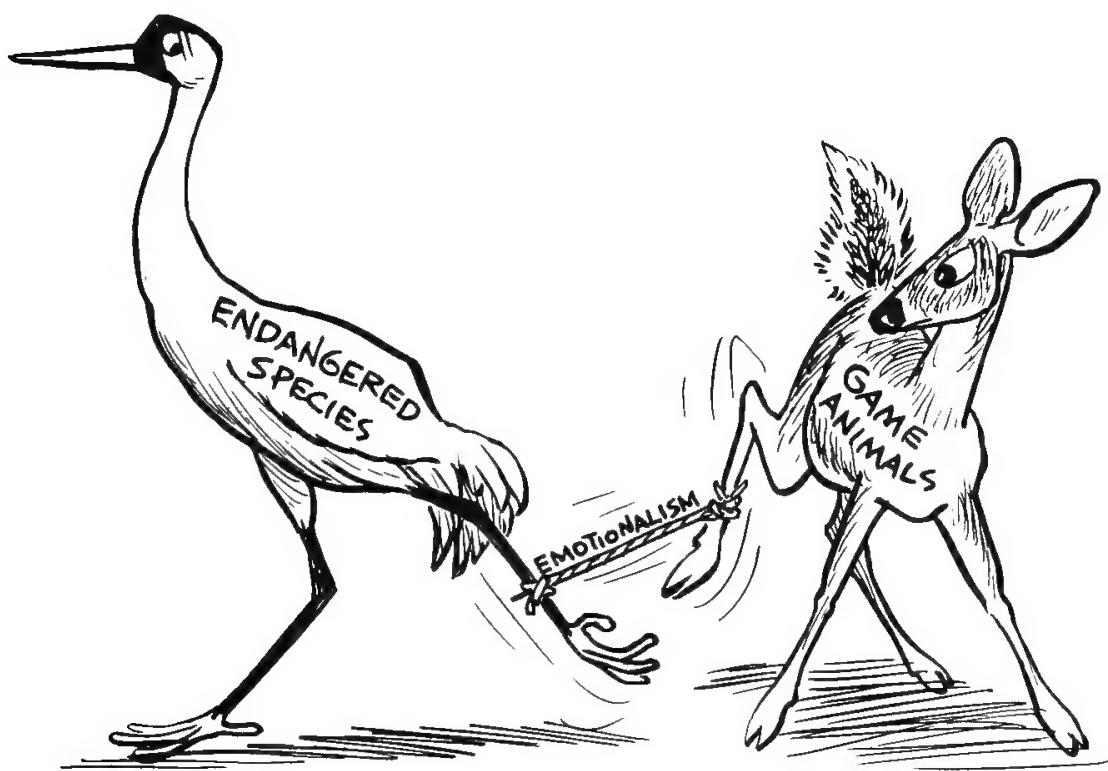


As with all emotion-tinged issues, however, there is tendency to overstate the case. Some journalists distort the status of American wildlife in general, the steps needed to maintain wild populations, and the actions required to reverse declines of species that really are threatened. Because of such misinformation many interested persons get the impression that all American wildlife is endangered. This view is unsupported by facts.

That man and his works have destroyed a number of species and greatly reduced others that were abundant in early times is well-known. Less well-known is the fact that many species, some of which were rare in colonial times, are thriving today largely because of compatible human influences on the environment, well designed private management efforts, and sound state and federal wildlife management programs.

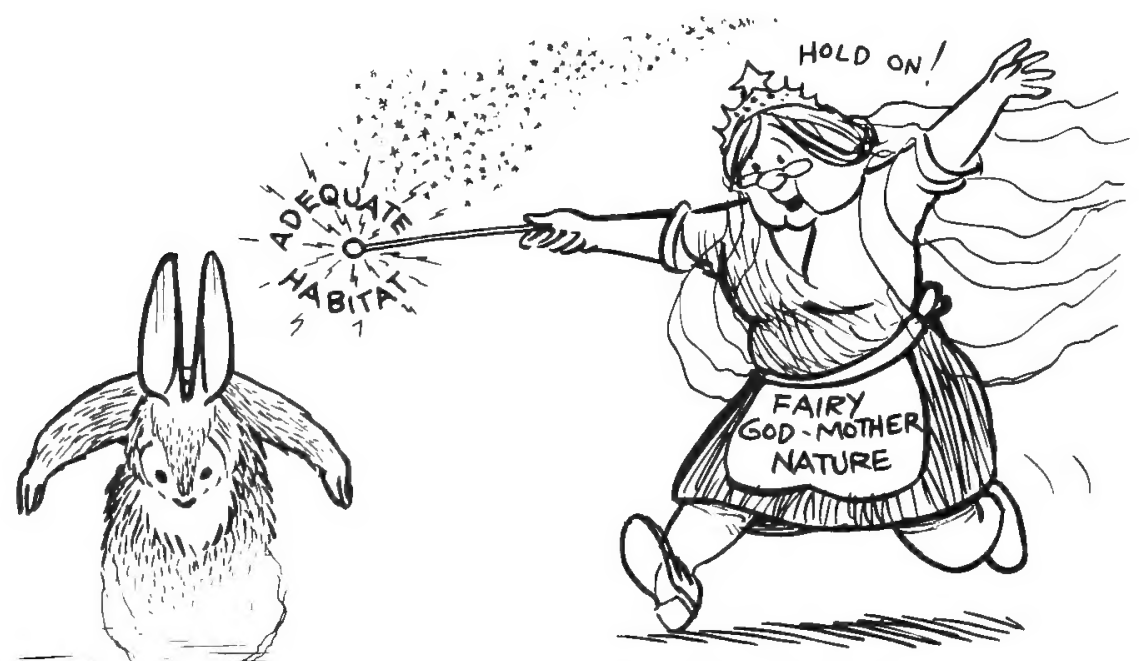

ALL WILDLIFE REQUIRE ADEQUATE. HABITAT TO SUSTAIN POPULATIONS

All wildlife is affected in one way or another by man. But man can build as well as destroy. Of all of the creatures on earth, he is the only one with the ability to tailor the abundance of most species to fit his desires. With some birds and mammals this can be done with minimum effort because human changes in the environment favor their increase or their needs are not as critical. With others deliberate and often expensive programs must be developed to maintain specific habitats. Actions needed to save one species may be entirely different from those needed to save a second. But all wild animals require adequate habitat to sustain their populations and breeding stock from one year to the next. 


\section{Habitat - The Vital Element}

Food, water, and cover used to escape enemies and adverse weather are the essential parts of the habitat of every species. But the specific habitat needs of each species vary in some degree from those of every other kind of animal, although many different animals may occupy the same general area.

The water requirements of a desert jackrabbit obviously differ greatly from those of a beaver. What might be year-round food and cover for a meadow mouse would be little more than a full day's meal and no cover at all for an elk. Many migratory birds occupy and need widely different types of seasonal habitats separated by hundreds and often many thousands of miles. Some large mammals, like caribou and cougars, range over wide areas to find their year-round needs. Small animals, like shrews and moles, may live out their lives in one small corner of a field or woodlot.

Some species need a highly specialized type of habitat. Most woodpeckers require dead and dying trees to supply their insect foods and nesting sites. But the Gila woodpecker of the desert Southwest digs its nesting holes exclusively in the larger cacti.

Some species, like the California condor, can stand almost no human disturbance. Others, like the common pigeon and English or house sparrow, thrive in the most populous cities, nesting on buildings and garnering meals from human handouts and leftovers.

When the habitat needs of every species and subspecies are computed in detail, the range in variety is almost infinite.

Whenever local conditions change, the species composition of the local wildlife populations also changes. Some species may be eliminated, others decline, and still others increase. If changes remove any of its essential habitat requirements, a species cannot continue to live in the area affected. If habitat of the kind it needs is reduced to remnants, the species will become endangered. If it is eliminated everywhere, the animals will become extinct. In the absence of adequate habitat, protection of individual animals is meaningless in terms of perpetuating wild populations.

Wildlife now threatened and endangered can be maintained only by protecting those populations that still exist and preserving what remains of their vital habitats. But their numbers can be increased by expanding and improving suitable habitats.

This does not mean that threatened and endangered wildlife can be saved only by denying or limiting human use of the land. Rather, it means that such use be done with thoughtful planning and with full consideration for wildlife's needs. Incorporation of such considerations in all programs affecting the landscape would assure a future for America's varied wildlife. 


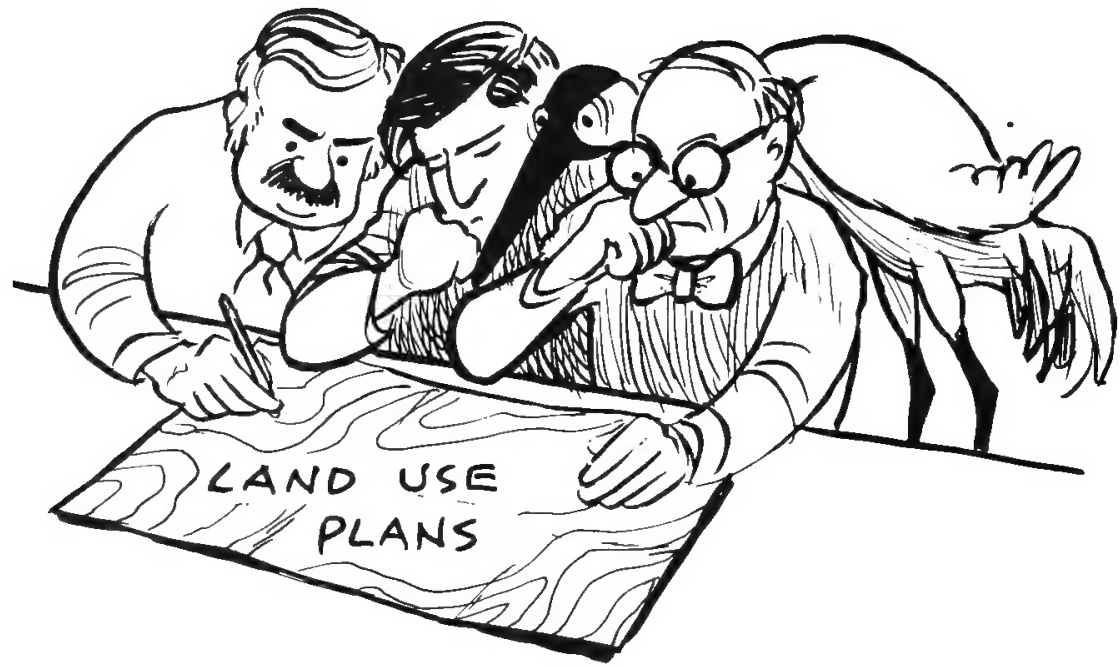

\section{Habitat-Population Relationships}

The potential for increase in wildlife populations in ideal habitat almost defies belief. In 1900, there were virtually no wild deer left in Pennsylvania. The state's original deer herd had been destroyed early in the 19th century by landclearing for agriculture, overgrazing, by destructive timber cutting followed by wild fire, and by unregulated shooting. After the Civil War, with increased industrialization and the opening of the West, thousands of farmers abandoned their marginal lands to move to towns, gold fields, or fertile soils beyond the Mississippi. Behind them, the forests, under protection from wild fire, gradually began to reoccupy abandoned fields and homesites, creating the early-growth forests favored by deer.

Around the turn of the century, sportmen's organizations and the Pennsylvania Game Commission purchased a relatively few deer from other states and from private dealers, had laws passed to protect them, and released them into habitat that changing land use had made ideal for deer. Twenty-five years later, Penn's Woods held nearly a million whitetails, almost twice as many as the available range could support through winter.

Potentially, a deer population can more than double every second year. One doe can produce 15 or more fawns in an average life span of eight years. If all her young and theirs survive to the same age and breed as successfully, they would number 150 or more before her death. Many animals - songbirds, rabbits, squirrels, quail and ducks, for example can increase at even greater rates. 
Obviously, when a population of a particular species begins to multiply, something has to give - and it does. Each piece of land has a limit on the number of animals of any one species that it can support. Wildlife biologists call this carrying capacity. It is the capability of an area to provide a species' food, water, shelter, and other needs in a given season. Once carrying capacity is reached, the surplus animals must move elsewhere or die. If suitable under-stocked habitat is not available within their range of mobility, the surplus animals are doomed.

The tendency of populations of nearly all wild species is to expand rapidly to the carrying capacity of the available habitat. In some species, like pheasants and rabbits, which often produce ten or more young in a single breeding season, this level can be attained very quickly, even by a reduced breeding population. In other species, such as bears, which rarely breed until they are several years of age and then produce fewer young, the rate of increase is slower. But nature compensates by endowing the slower reproducers with longer lives.

For many species, particularly the smaller animals, nature's scheme is to produce an overabundance of young. This increases the likelihood that some will survive to perpetuate the species in spite of the inevitable toll taken by adverse weather, disease, starvation, predators, and other hazards. Most wild animals in North America produce all of their young during a restricted season of a few weeks, usually in the spring or early summer. In northern or temperate areas, summer carrying capacity is far higher than that of winter because of the abundance of plant and other life. A relatively small patch of cover may contain a population of a dozen or more cottontail rabbits in early September, but few are likely to survive until March. No more than 35 percent of the young mourning doves produced in summer live until the next breeding season. The higher the reproductive rate of a species, the higher its natural mortality rate. In the wild, animals that produce many young have short lives and lose most of their young in their first year.

Nature has many methods for regulating wild populations. One of these is territorialism - the tendency of breeding animals to defend a given area. Some sea birds nest almost shoulder to shoulder in dense colonies, but they will not tolerate the presence of other birds within reach of their nests. The lilting song of a male house wren is not a song of joy, but a warning to all other wrens to keep away from his nesting territory. If an intruder ventures too near, the defending male will attack with righteous fury. A cock pheasant may gather a harem of six or more mates and defend a crowing area approaching an acre or more. A male grizzly bear, in breeding season, may defend 20 or more square miles from all other males of his kind.

Such natural population controls are nature's way of assuring that only the stronger, quicker, and more alert animals of each species survive until breeding season and perpetuate the species.

At times, a series of mild winters and unusually favorable conditions over several breeding seasons may temporarily raise the normal carrying 


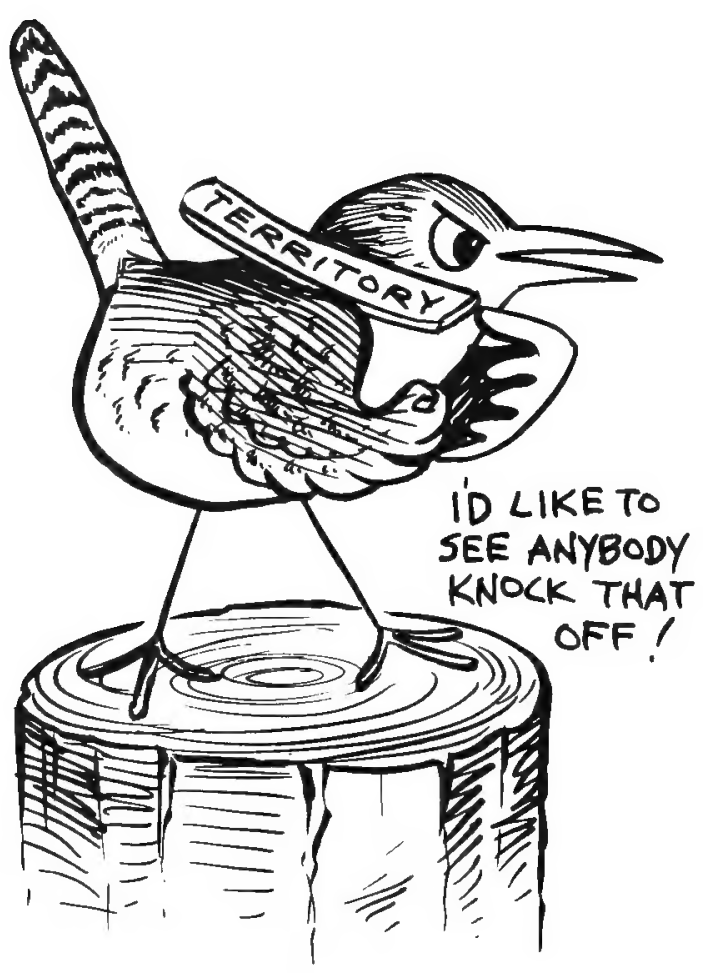

capacity and the populations of animals that depend on plants. When weather conditions return to average, crowding leads to stress and competition for food, space, and mates and permits the spread of diseases. Winter food supplies become inadequate and malnutrition, diseases, and predators take heavy tolls. In turn, populations of wolves and other predators that feed on the plant eaters are regulated by the abundance or scarcity of the animals on which they feed.

Overpopulations can be especially disastrous to large browsing and grazing mammals, like deer and elk. Where overabundant, such animals can cause great damage to their own habitats, resulting in a much reduced carrying capacity for many years. That is what happened to the Pennsylvania deer herd in the late 1920's. Hundreds of thousands of deer died of starvation and disease in a series of bitter winters before the numbers could be lowered by regulated hunting to the carrying capacity of the winter range.

Even in some wildlife refuges and national parks, elk and deer herds must be thinned to prevent overabundant animals from destroying their food supplies and damaging the food supplies of other species. The lesson here is that man and his activities have so interrupted wildlife's natural cycles and systems in most places that only through deliberate management can mankind assure the survival of most species of wildlife. 


\section{The Role of Protection}

Protection plays an important part in wildlife management. The best habitats are of no value to wildlife if there are no breeders to occupy them. But to argue that total protection is the answer for all wildlife problems is a dangerous oversimplification. It ignores the differing needs of the various species.

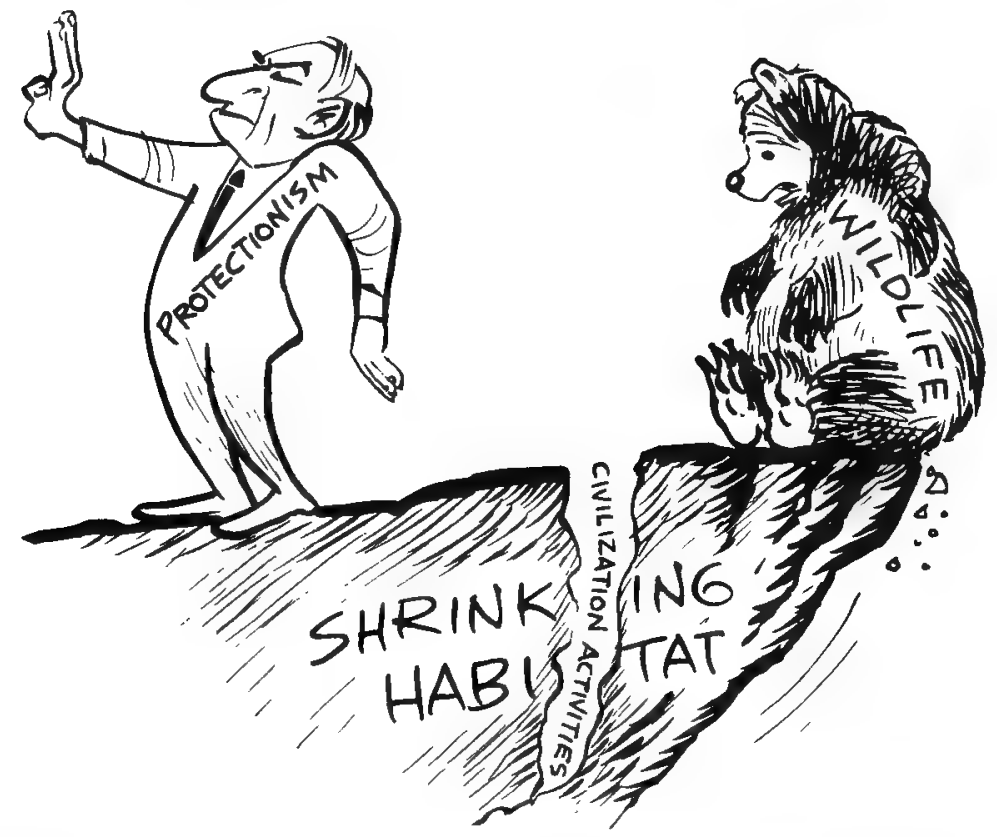

With the exception of a few species considered pests in certain situations, nearly all birds and mammals receive some degree of legal protection. Songbirds, eagles, hawks, egrets, and many other types of birds are granted continuing protection under state and federal laws. Most states provide full legal protection for endangered species found within their borders. At the federal level, the endangered species programs and the new world treaty governing trade in threatened and endangered species provide additional protection for our less common forms of wildlife. Violators of these laws risk heavy penalties in state and federal courts.

But the degree of protection needed by the different species varies as widely as their habitat requirements. The loss of only a few individuals of an endangered species like the whooping crane or California condor would be critical. On the other hand, the coyote, in spite of persecution since early times, thrives in the face of adversity. It remains common on most of the western prairies and has extended its original range into the South and East. 
Animals classed as game under state and federal laws may be hunted, but they are not without protection. They may be taken by hunters only under regulations that prescribe calendar dates, hunting hours, bag limits, and methods of taking. Under certain circumstances, hunting seasons for some game species may be closed completely. All game species are protected by law while they are nesting and raising their young. These regulations, based on careful research, are designed to assure the carry-over to the next breeding season of enough animals to repopulate the available habitat.

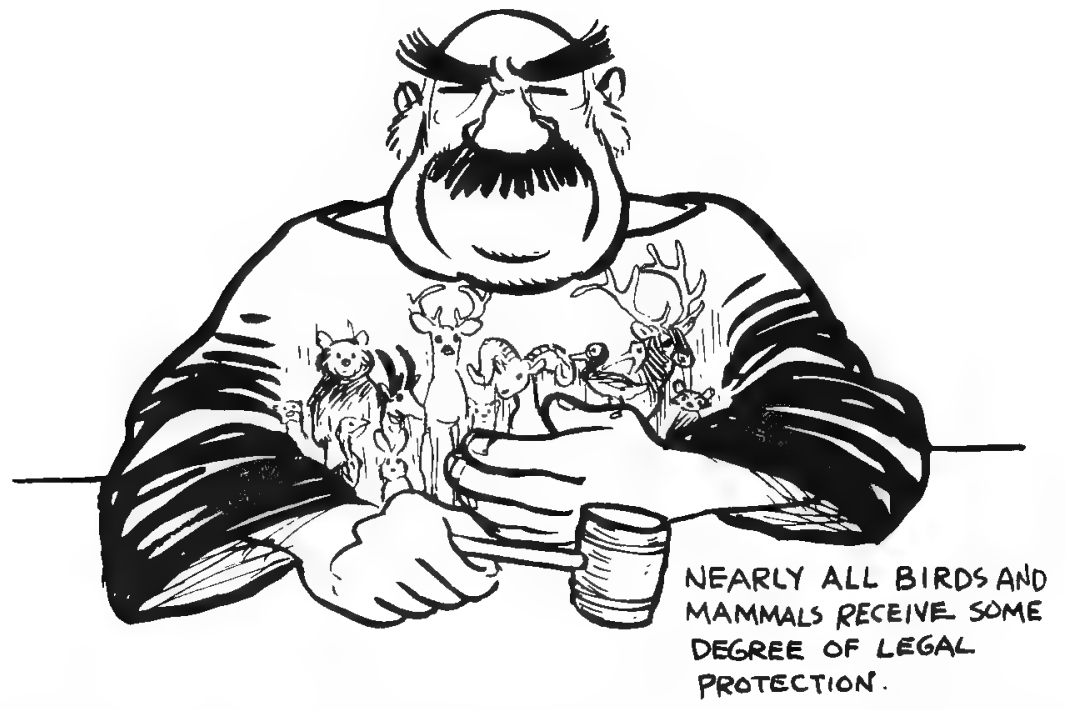

There are situations under which it may be necessary to reduce temporarily the population of one species to benefit another. Although gulls are protected by state and federal laws, legal protection of herring gulls nesting on islands off the Massachusetts coast was suspended for a while to permit the poisoning of some birds and destroying the eggs of others. The reason - the breeding gull population had mushroomed because of the presence of nearby mainland garbage dumps, and the abundant gulls were eating the eggs and young of the much rarer terns that formerly had the islands nearly to themselves.

In order to reestablish a species in suitable unoccupied habitat, it may be necessary to temporarily reduce the numbers of predators in the area until the released animals multiply and become familiar with their new surroundings. After prey species increase above the threshold level, predators are just one of the many factors bearing on the population's survival.

Predation is not all bad, in fact. By falling victim to a fox or an owl, for example, the prey helps perpetuate a higher and equally valued order of life. 

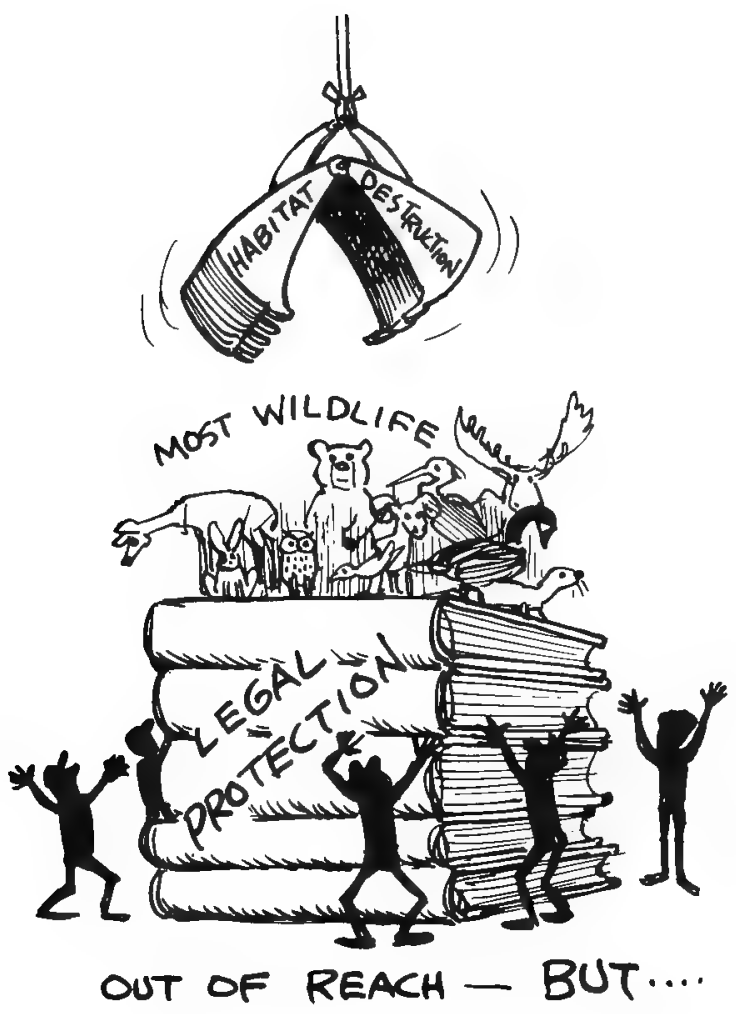

\section{The Real Threat to Wildlife}

Man rarely sets out deliberately to exterminate a wild species. Some, like the coyote and crow, that settlers marked for extermination, still thrive in spite of massive trapping and poisoning campaigns. But most of man's adverse influences on wildlife have been unintentional and inadvertent.

Man, his works, and his livestock compete with wild animals for food and space. Actually, the effects of habitat destruction are worse than direct killing, because unoccupied wildlife habitat can and, in time, usually will be reoccupied. Habitat that is drastically altered or destroyed can never support its original wild populations.

Housing developments, highways and airports, hydroelectric and irrigation reservoirs, factories, and mines contribute to the American standard of living. But each new residential or industrial expansion reduces the habitat base upon which many wildlife populations depend.

Even some practices associated with farming and forestry can adversely affect wild populations. Large mechanized farms devoted to single crops, like wheat, and extensive, closely planted pine plantations 
provide few of the needs of wildlife. Sanitation cuttings that remove all hollow, dead and dying trees and sprawling nut- and mast-producing hardwoods eliminate the dens, nest sites, and food of many forest species.

Draining and filling marshes, potholes, and other wetlands to expand croplands, commercial and industrial complexes, and transportation systems pose major threats to waterfowl and other wildlife. Coastal marshes, favorite sites for factories, refineries, and airports, are among the most productive types of habitats for a wide range of fish and aquatic wildlife. Channelization can destroy the habitat of animals frequenting rivers and streams.

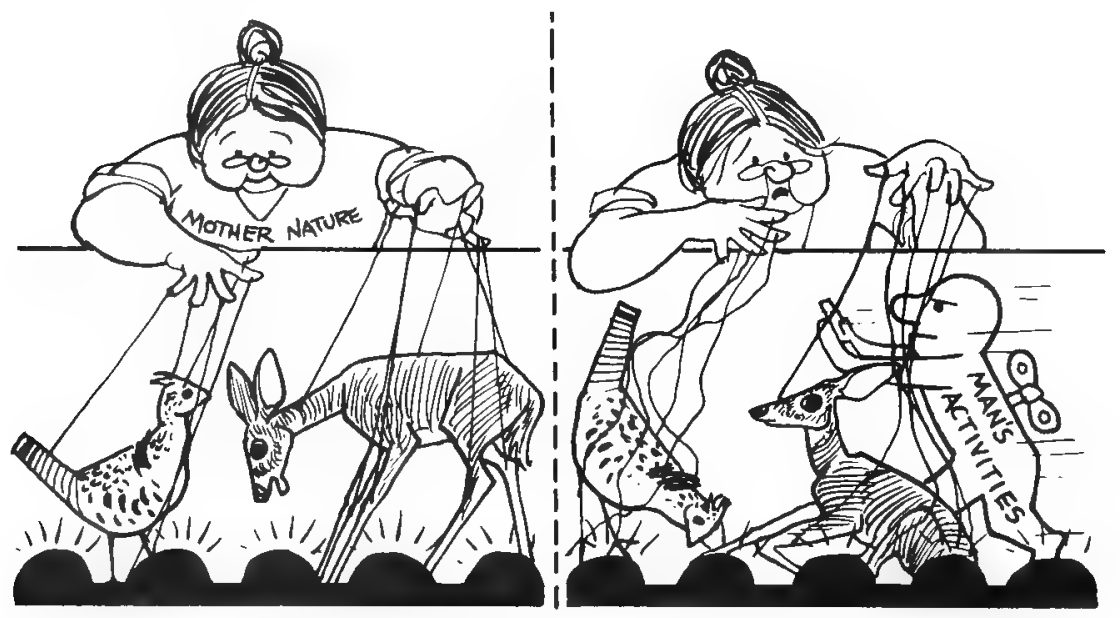

MAN AND HIS ACTIVITIES HAVE INTERRUPTED WILDLIFE'S NATURAL CYCLES AND SYSTEMS.

Livestock grazing can improve conditions for some wildlife, but overgrazing can exclude most wildlife use, often for many years. Largescale brush-clearing to favor grasses can eliminate food and cover needed by many birds and mammals.

Modern technology has produced a broad range of pollutants with which wildlife must contend. Some, like certain pesticides and mercury, kill directly. Others, like DDT, operate more subtly on the animals' reproductive systems, cause eggshell thinning in some birds, and depress hatching success in others. Acid mine wastes and industrial pollutants destroy vegetation essential to the survival of many species.

These and many other critical environmental problems concern the wildlife manager. Often his recommendations, if applied, can have a major influence on the continued survival of one or more species in a given area and help maintain nature's functioning systems.

Only through careful guidance of all human activities that affect wildlife, both indirectly and directly, can their populations be assured. 


\section{Hunting and Wildlife Conservation}

Sport hunting is recognized as a legitimate use of surplus wildlife by state and federal laws traceable in origin to the Magna Carta. These same laws establish the rights of the states to control the activities of hunters. Hunting is now regulated under comprehensive laws in every state. These are supplemented by federal laws applying to certain species, including migratory birds, and to the interstate shipment of wild animals and their products.

This was not always the case. Before the turn of the century, restrictions on shooters were few, and those laws that existed were poorly enforced, when enforced at all. In the early days, when the pioneer philosophy prevailed and many Americans lived off the land, nearly all edible or useful forms of wildlife were taken almost without restrictions at any time. "Useful" meant any bird or mammal that could be eaten or sold for its meat, feathers, fur, or other parts.

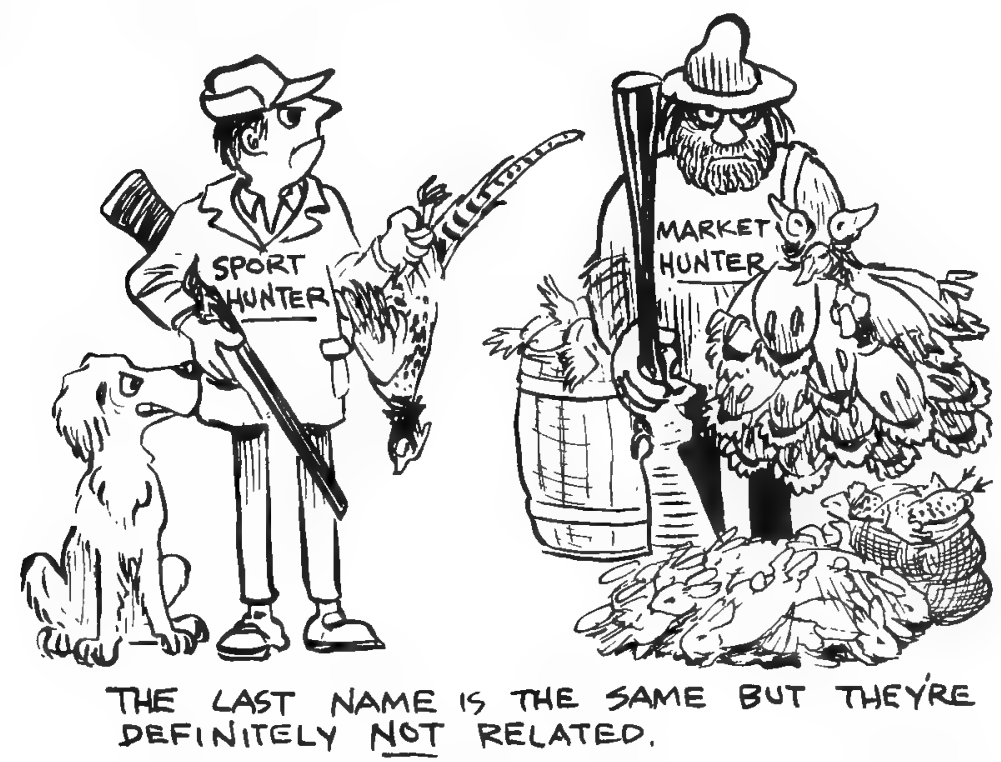

The brutalities historically attributed to hunters - the slaughter of the buffalo, the decimation of the sea otter, the extermination of the passenger pigeon, and others - involved mainly paid butchers who had no relationship at all with the modern sport hunter. The common use of bird plumage to decorate ladies' hats in the Gay Nineties and early 1900's nearly doomed the egrets and other plume-bearing birds before state and federal laws backed by firm enforcement checked their slaughter. Until comparatively recent times, any birds or mammals that eat meat - from sparrow hawks to grizzly bears - were considered enemies of the farmer or rancher and subject to killing on sight. Massive poisoning and trapping campaigns, largely by federal agents and professional hunters 
employed by livestock organizations, wiped out the prairie wolves and greatly reduced the numbers of cougars and bears. Now, these abuses, which were stimulated by economic concerns, have been substantially checked by a growing public appreciation of the many values of predators and of wildlife in general.

In recent times, demands for alligator hides by makers of shoes, wallets, and other leather goods, attracted poachers and illegal hide buyers to the swamps and bayous of the South. Their activities continue to be curbed by aggressive state law enforcement and by bringing the alligator under the protection of a long-standing federal law that prohibits interstate commerce in wildlife products taken in violation of state laws. Thus, state and federal conservation forces were united in correcting the problem.

From the standpoint of wildlife conservation, hunting must be judged solely on its effect on the species of animals hunted. The fact that many designated game species have increased steadily in numbers over the years, in spite of growing numbers of hunters with greater mobility, testifies to the effectiveness of scientific wildlife management. It also shows that the carefully regulated modern hunter has no long-term negative effect on the comparatively few wildlife species he pursues. This conclusion is based on research in many regions of the country. Therefore, with properly regulated sport hunting having no adverse effects, the decision of whether to hunt or not to hunt is a matter of personal choice.

As with any large representative group of Americans, there are among hunters a minority who fail to abide by the laws and rules of sportsmanship. These people, when their activities are not checked by effective law enforcement and the disapproval of the public - especially by sportsmen - can have undesirable impacts on local wildlife populations and create unfavorable reactions to hunting and hunters.

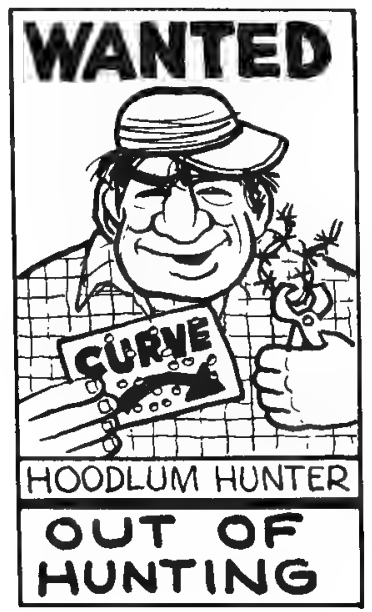


Regulated hunting, however, properly applied, is an important tool of wildlife management. The annual cropping of grazing and browsing animals whose populations are near carrying capacity lowers the annual loss from disease and malnutrition. It prevents the animals from becoming so numerous that they deplete their own food supplies and the food and cover upon which other species depend. Wild populations that are below carrying capacity are far healthier and produce more young than those at or near the capacity of the range.

Virtually all of this essential wildlife management is financed by funds obtained from sportsmen. By purchasing required federal duck stamps. waterfowl hunters annually contribute around $\$ 10$ million to federal waterfowl and wetland conservation programs. Like any other citizens, of course, sportsmen also pay federal income taxes that support national wildlife and allied resource programs. But more important, their license fees and special taxes provide about a quarter of a billion dollars each year for the basic support of the state fish and wildlife conservation programs. Few state wildlife agencies receive funds from the general public.

Sportsmen also contribute to wildlife conservation through private organizations. Many local and state sportsmen's organizations have active cooperative programs that maintain and increase wild populations on private lands without cost to the public. Ducks Unlimited, an association of waterfowl hunters, has created or restored more than 1,000 Canadian waterfowl production areas covering more than 2 million acres. These critical wetlands provide habitat for more than 200 species of wildlife.

Sportsmen's state hunting and fishing license fees are used to buy, maintain, and improve wildlife habitat that benefits both hunted and unhunted wildlife on public and private lands and to provide the modern equipment needed to enforce laws for the protection of wildlife. They make it possible to employ many thousands of managers, biologists, and conservation officers to protect and care for wildlife. Many state wildlife agencies own or control large land holdings that are managed intensively to maintain wildlife populations at desirable levels.

Some critics of the American system of wildlife management have charged that because hunters and fishermen carry the financial burden of wildlife conservation, the state agencies favor game species in their programs and ignore nonhunted species. This overlooks the fact that many state wildlife agencies have excellent nongame wildlife programs. Habitat created or maintained for pheasants or quail additionally benefits a wide range of nonhunted species, from meadowlarks to hawks and owls. Most serious birdwatchers know that some of the best birding is found on state wildlife management areas and refuges. Waterfowl management areas provide food and cover for a host of nongame species, ranging from marsh wrens to ospreys and eagles. 


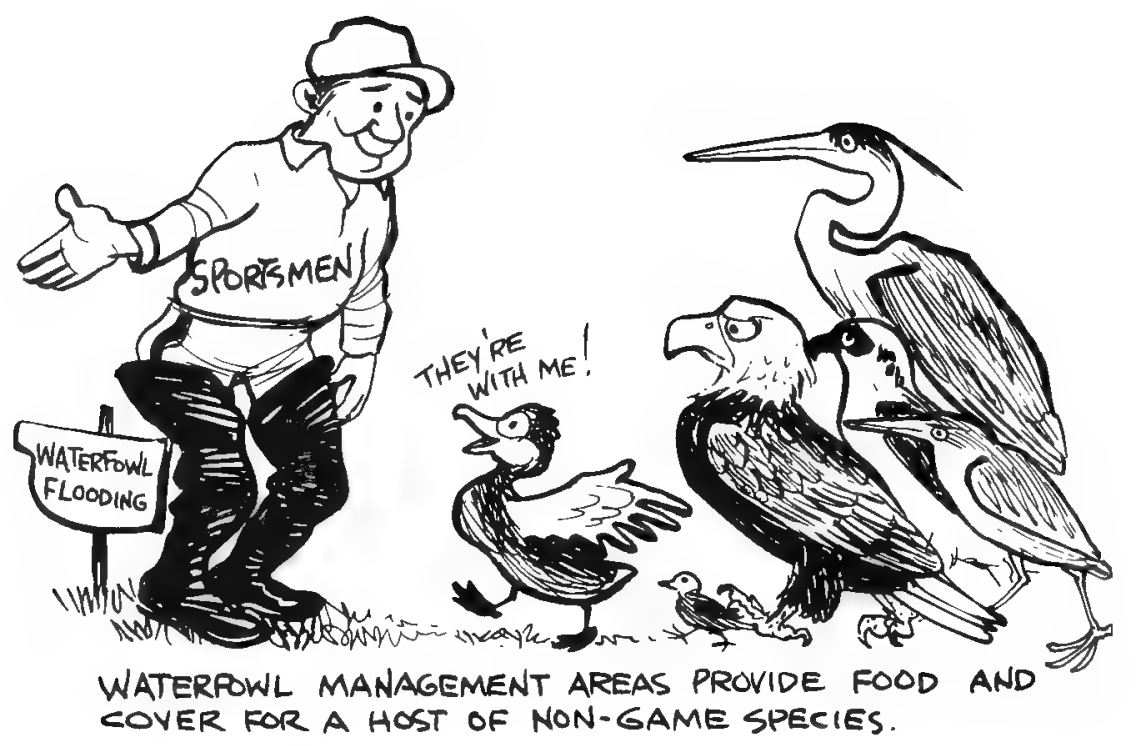

While most state wildlife agencies would welcome financial support from the general public, state legislators have been reluctant to supplement fishing and hunting license revenues with general fund appropriations. In 1937, a federal law, the Federal Aid in Wildlife Restoration Act, was passed by Congress. It allocated to the state fish and wildlife agencies receipts from an existing, 11 percent excise tax on sporting firearms and ammunition for the purpose of conducting approved projects of wildlife research, land acquisition and development, and restocking of unoccupied habitats. To qualify for this assistance the states had to pledge all hunting and fishing license funds to conservation purposes. Before that time it was common practice for state legislatures to divert income from hunting and fishing licenses for schools, highways, and other public works, while the state wildlife agency obtained only a part of the funds for actual use for fish and wildlife conservation.

Until state legislatures show more willingness to support wildlife programs with revenues from other sources, sportsmen will continue as the principal source of financial support for wildlife conservation. The reluctance of the general public and state legislatures to support necessary conservation programs overlooks the great social and economic benefits of sound wildlife management.

Individuals and groups interested in wildlife should bear in mind the animal's basic need for habitat. Secondly, they should seek to strengthen the state-federal system to assure the well-being of all wildlife. Distortion of the true facts with respect to America's wildlife only misleads the public. Further, it confuses lawmakers, who, in their efforts 
to respond to public concerns, sometimes resort to well-intentioned but ineffective remedies. The best thing that could happen to wildlife would be for all concerned Americans to join hands in working for truly needed programs. In this way, they would assure that adequate and effective steps are taken to restore depleted species and to prevent others from becoming endangered.

\section{Extinct, Endangered, and Threatened Species}

To clearly understand endangered wildlife, it is necessary to know some technical terms that are widely used but imperfectly understood.

Congress enacted Endangered Species Conservation Acts in 1966, 1969, and 1973 to help check the decline of America's rarer forms of mammals, birds, fish, reptiles, amphibians, invertebrates, and plants. These legal mandates are administered through an Office of Endangered Species in the U.S. Fish and Wildlife Service.

Legal definitions used in these Acts do not always conform with strict dictionary definitions. Under terms of the Acts, a species or subspecies is endangered when officially declared in imminent danger of extinction by the Secretary of the Interior after consultation with scientists. Threatened species are those officially declared likely to become endangered in the foreseeable future over all or a "significant portion" of their ranges. Lists of these animals, amended periodically, are published in government documents.

A species in the scientific sense, is a group of animals sharing common characteristics that are passed on to their offspring and whose members can produce fertile young only by mating within their own group. A subspecies is a group of animals of the same species that has developed common distinctive characteristics because they evolved in isolation from other subspecies of the parent species. Differences may include color, size, or bone structure. Although the differences are artifically maintained, an extreme example can be found in the variety of breeds in the domesticated dog. Among wild animals, some subspecies differ so much from others of the same species that the layman would consider them unrelated. But members of different subspecies can interbreed and produce young that are capable of successful breeding. 
As used in the Endangered Species Acts, the term "species" includes various subspecies. Even scientists and writers who know the distinction often refer loosely to subspecies as "species." This leads to public confusion. The official Endangered Species List may include a localized

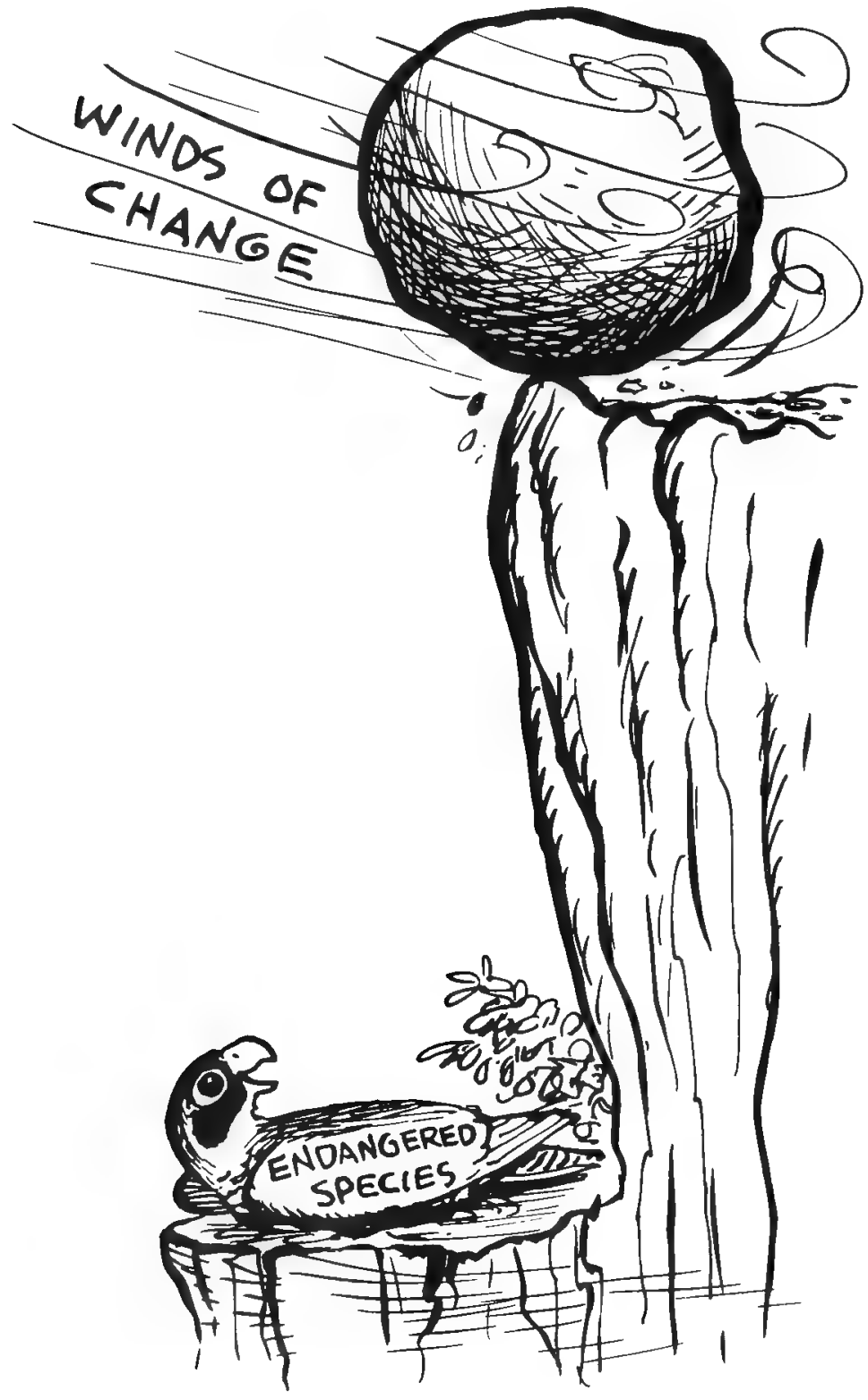


subspecies that is represented elsewhere by other abundant and widely distributed subspecies. This often leads the public to believe that the entire species is endangered when only a small population segment is in trouble. The endangered Delmarva fox squirrel, for example, is confined to a small area in eastern Maryland and Virginia. But other kinds of fox squirrel are common to abundant in the southeastern and midwestern United States.

Forty known kinds of birds and mammals native to the United States and its territories have become extinct: 109 animals, of which 64 are birds and mammals, have been declared endangered by the Secretary of the Interior.

At face value these figures are alarming. But the situation in North America is not that bleak. Only six of the 32 extinct species and subspecies of birds were native to the North American mainland. Most were native to Hawaii.

Species and subspecies that have evolved in restricted island habitats are especially vulnerable. They depend for survival upon unique and fragile ecosystems that change dramatically with any intrusion of man. Evolution in isolation has equipped few island species to cope with introduced predators, such as house cats, rats and mongooses, or to resist introduced diseases.

Civilized man has brought wild and domesticated birds and mammals from his homeland to every island he has settled. Native animals usually are unable to compete with the more aggressive invaders. Grazing and foraging by sheep, cattle, goats and pigs often destroy vital wildlife habitats. Since its discovery, 40 percent of Hawaii's original forms of birds have become extinct, and another 40 percent are endangered, largely because of inadvertent human influences.

A large majority of the endangered animals and those that have become extinct were island species, literally or figuratively, in that their restricted habitats were surrounded by terrain unsuitable for their survival. Of the eight extinct North American mammals, two were meadow mice or voles. One was confined to a single small island in Long Island Sound; the other occupied an isolated marsh in California. The range of the heath hen was reduced to one island off the coast of Massachusetts soon after the American Revolution. In spite of 50 years of total protection, it became extinct in 1932. The population had been built to nearly 2,000 in the late 1920 's when fire swept its nesting grounds at the height of the breeding season. Introduced poultry diseases eliminated the survivors.

Today, the heath hen's close relative, the Attwater's prairie chicken, occupies a similar vulnerable habitat on a small section of the Gulf Coast of Texas. The natural grasslands that it needs were much reduced and are now surrounded by cultivated lands and heavily grazed pastures.

Habitat factors even played a role in the fate of species that were destroyed or reduced to remnants principally by direct, deliberate killing. Commercial netting was a major cause of the extinction of the 


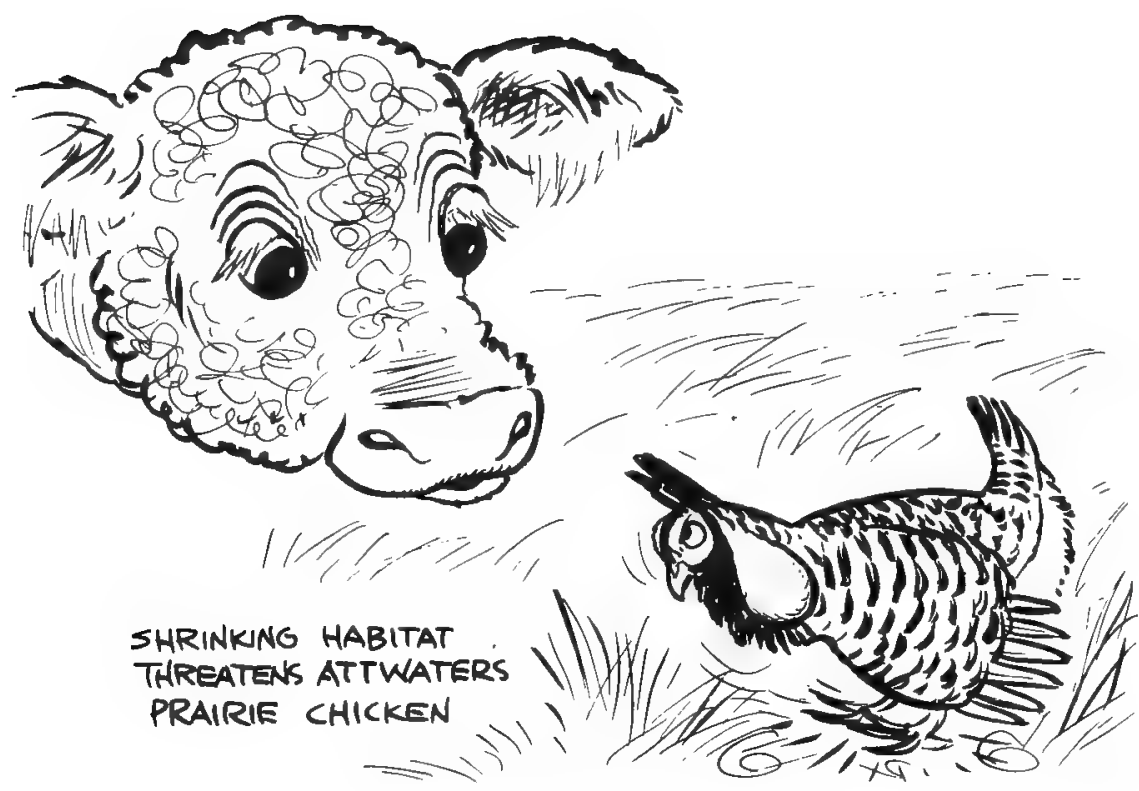

passenger pigeon. But the clearing of the northern hardwood forests for agriculture concentrated the nesting colonies and the activities of the netters. Steller's sea cow was butchered to extinction by Russian seal hunters before the American Revolution. The great auk, which became extinct in 1844, was slaughtered on its nesting grounds by whalers for its eggs, plumage, and oil. All of these animals gathered in dense breeding colonies that made their killing easy. All were destroyed by unregulated commercialism long before there was more than rudimentary public sentiment for wildlife conservation.

The Badlands bighorn sheep, Merriam's elk, and eastern elk were decimated by meat-seeking settlers, prospectors, and market hunters before 1910. All occupied restricted and vulnerable habitats, and all suffered from competition with livestock and agriculture. State and federal wildlife agencies have introduced closely related subspecies of bighorn and elk to the original range of the first two animals. Most of the range of the eastern elk has been taken over by agriculture, but elk of closely related subspecies have been restored to Virginia and Michigan.

Modern sport hunting, as now regulated, has no relationship to the thoughtless commercial exploitation of wildlife of the past. The vast majority of the birds and mammals on the endangered list occupy highly specialized habitats. Some were not abundant even in early times. Kirtland's warbler, a tiny migratory bird that nests only in Michigan, must have jackpines between 5 and 18 feet high to nest successfully. Historically, this habitat was created by naturally occurring forest fires. But foresters in their efforts to develop commercial timber excluded fire 


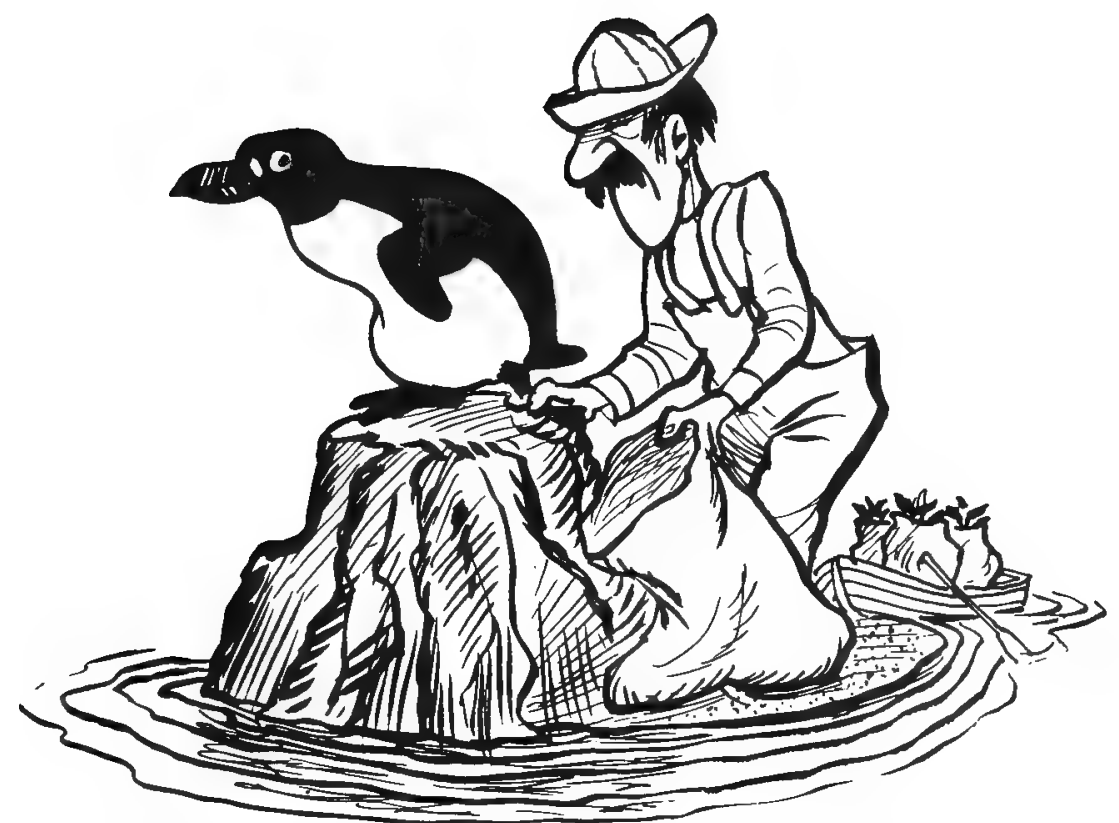

\section{COMMERCLAL EXPLOITATION PLUS RESTRICTEO OR DISAPPEARING HABITAT CAUSED EXTINCTION OF MANY SPECIES - LIKE THE GREAT AUK.}

from the woods and nearly eliminated the bird's breeding habitat. Today, wildlife managers and foresters are using prescribed burning in special refuge areas to maintain jackpines at their most attractive stage of growth for the warblers.

The ivory-billed woodpecker needs large areas of old-growth forests, with their dead and dying trees. Forests of this kind are disappearing because of the accelerating demand for agricultural and timber products. The black-footed ferret, never an abundant species, was unthinkingly reduced to an endangered status by the widespread poisoning of its primary prey, the prairie dog.

Most predatory birds and mammals have been persecuted for centuries because of their threat - real or imagined - to livestock, poultry, fish and game. Now, when predators are more widely appreciated, new threats have arisen to plague these interesting animals. Persistent pesticides, notably DDT and related substances, are absorbed from the water in the tissues of fish and other aquatic animals. As larger birds feed on fish and small animals low on the food chain, the contaminants concentrate in their tissues. The result is greatly reduced nesting success by larger fish-eating and predatory birds. The rapid decline of the bald eagle, peregrine falcon, and brown pelican is attributable primarily to pesticides. 


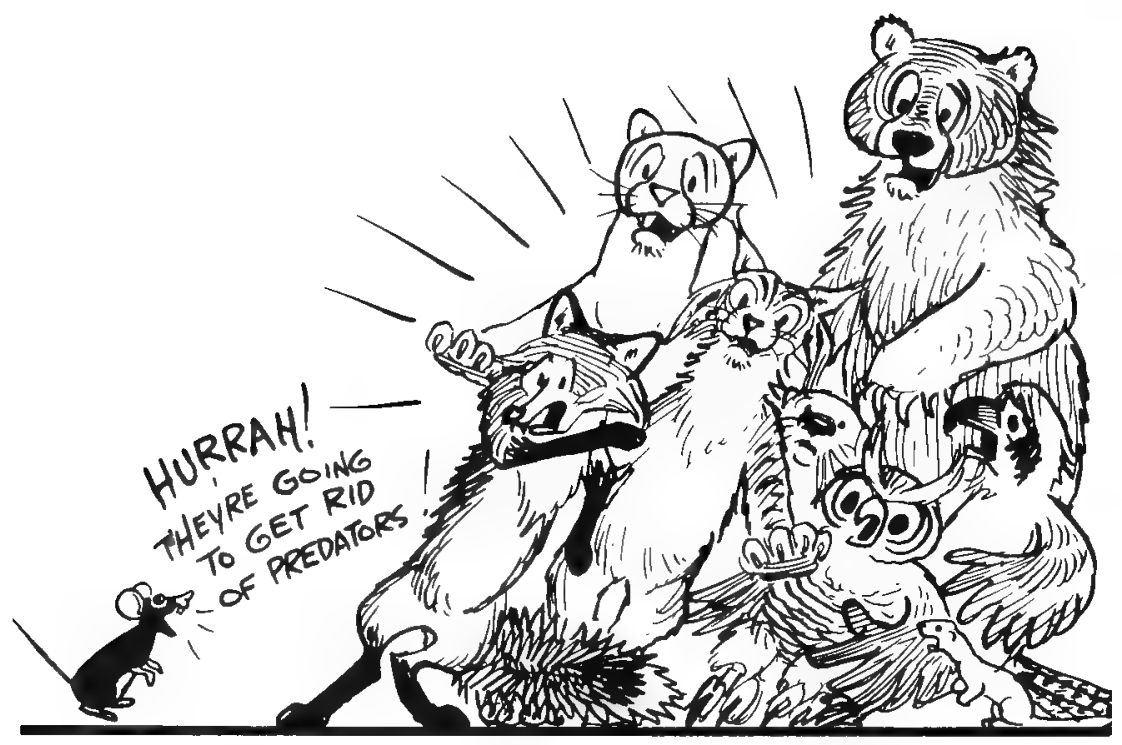

Several species, like the ivory-billed woodpecker and Eskimo curlew, have been so reduced in numbers that there is little hope for their survival, if any still exist. But many animals now threatened or endangered could be restored to safe levels, if not abundance. This has already been demonstrated.

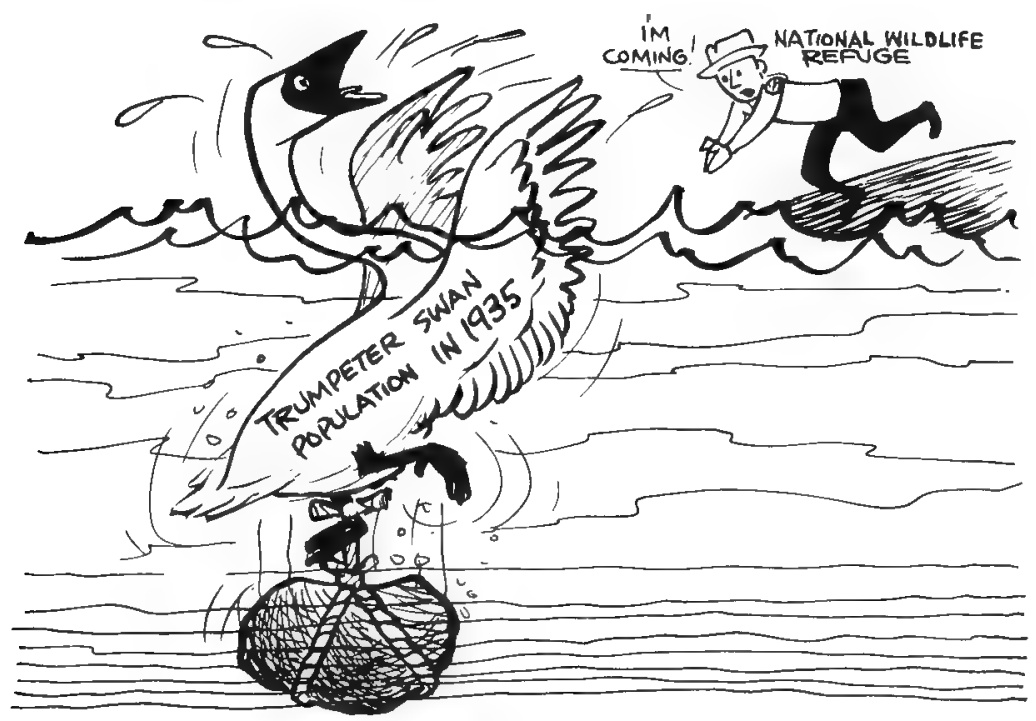


In 1935, trumpeter swans south of Canada were reduced to 73 on Red Rock Lakes and Yellowstone National Park in Montana. Since that year, when the Red Rock Lakes were declared a national wildlife refuge to protect the swans from irresponsible people and their habitat from intrusion, the population has responded well. Consequently, the trumpeter did not have to be included on the endangered species list. Other ancestral range in national parks and other western wildlife refuges support substantial breeding swan populations today. These resulted from the transplanting of surplus birds from the original refuge area.

The American alligator has increased rapidly in numbers under joint state and federal protection. Depleted habitat is now being repopulated with livetrapped and transplanted breeding stock. Federal and state authorities consider the alligator safe from extinction in most areas of the United States for the foreseeable future.

Many other species that are threatened or endangered today could be similarly restored through intensive management. The know-how already exists in the modern wildlife management profession. All that are needed are public and political support, time, and adequate funds to apply this knowledge.

\section{The American System of Wildlife Management}

The purpose of wildlife management is to maintain populations of wild animals at levels consistent with the best interests of wild species themselves and of the American public. Satisfying that objective is a big, complex job.

At the federal level, the U.S. Fish and Wildlife Service in the Department of the Interior is primarily responsible for regulating interstate and international traffic in wildlife and wildlife products and enforcing regulations applying to designated migratory birds. The Service administers the national wildlife refuge system, which provides protected and managed habitat for a wide range of wildlife species. It conducts research and maintains cooperative programs with state fish and wildlife agencies, private conservation groups, universities, and other federal land-management agencies. 


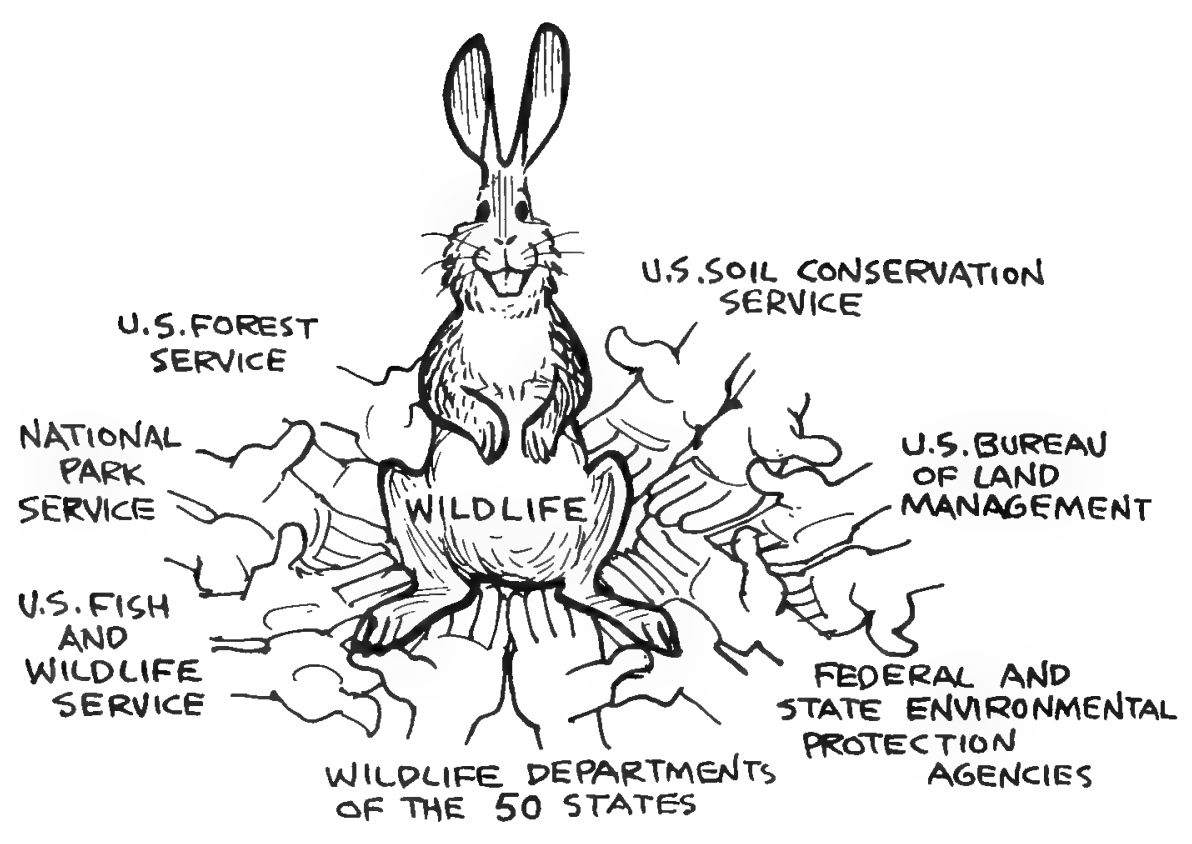

\section{WILDLIFE HAS MANY HELPING HANDS}

The Service is funded primarily from the U.S. Treasury to the extent of around $\$ 90$ million a year. It receives more than $\$ 10$ million annually from Duck Stamp revenues that are applied primarily to the expansion and development of the national wildlife refuge system. Each waterfowl hunter, 16 years of age and over, must purchase a federal hunting stamp each year.

The U.S. Forest Service which controls 187 million acres of national forests, and the Bureau of Land Management which administers 465 million acres of public lands, and the Soil Conservation Service also employ staffs of wildlife specialists whose salaries are paid by congressional appropriations. Considering the vast acreages of wildlife habitat involved, the manpower and funds available have been inadequate to cope with the magnitude of the task.

Each of the 50 states has an agency responsible for managing and protecting wildlife. These agencies are financed almost exclusively by sales of licenses to hunters and anglers and by receipts from federal taxes on sporting arms and ammunition and fishing tackle allocated to them for approved fish and wildlife conservation projects. The combined annual budgets of the state agencies, from these sources and others, exceed a third of a billion dollars. Approximately, $\$ 250$ million of this is derived from sportsmen. 


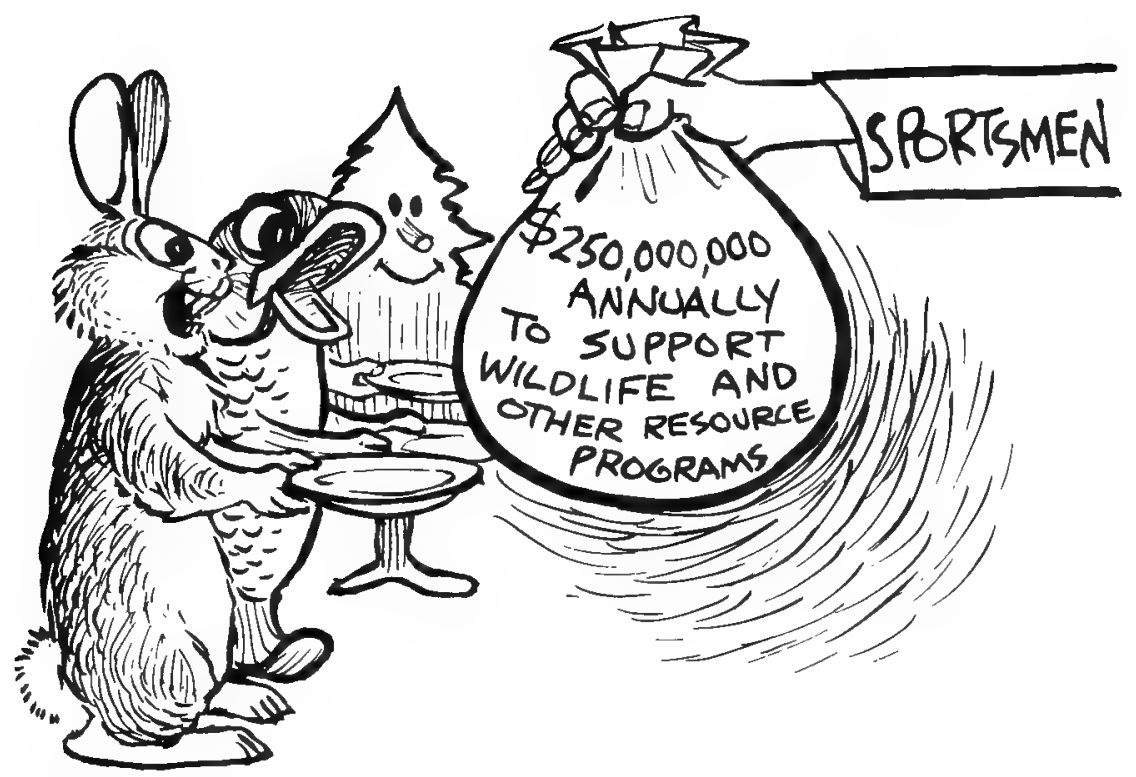

Although program emphasis and organizations vary, the typical state agency contains a research branch that obtains facts on the status of various species of wildlife and develops techniques for management; a management branch that maintains, improves and develops habitat, and performs such tasks as livetrapping and transplanting surplus wildlife; a law enforcement branch, responsible for enforcing the laws and regulations applying to fish and wildlife; and a branch of public education and information.

The state, under common law rooted in the Magna Carta, owns and holds in trust for its people all of the wildlife within its borders. In the case of migratory birds, marine mammals, eagles, and some other species, prerogatives for protection have been assumed by the Federal Government through its treaty-making powers and special acts of Congress. Since state laws affecting these species usually parallel the federal laws, these species generally receive dual protection. Federal and state conservation officers cooperate closely in protecting wildlife.

State fish and wildlife agencies own or manage more than 50 million acres for wildlife production. These refuges and management areas provide the habitat needs of a wide range of birds and mammals, unhunted as well as hunted. State wildlife managers also work with landowners and with state and federal foresters and land managers to improve, restore and maintain wildlife habitat on private and public lands.

Application of management has restored some wildlife populations, and holds promise for helping more. 


\section{Some Accomplishments of Modern Wildlife Management}

To appreciate the present, one must understand the past. Around 1900, most authorities did not have much hope for any of the larger forms of wildlife surviving far beyond the 1920's. This pessimistic view failed to foresee the scientific wildlife management programs that developed in the early 1930's and which have been expanded through subsequent decades. Here are a few historical comparisons:

- Beaver: 1900-Eliminated from the states of the Mississippi Valley and all eastern states except Maine: common only in Alaska and a few localities in the Pacific Northwest and Rockies. Today: Common to abundant in nearly all states except Hawaii.

- Pronghorn Antelope: 1925-Authorities estimated 13,000 to 26,000 in U.S.A., most in Wyoming and Montana. Today: Minimum population in all western states is 500,000 .

- Bison: 1895-800 survivors. Today: Population about 6,000 in U.S.A.; all available range fully stocked.

- Elk: 1907-Common only in and around Yellowstone National Park; estimated total south of Canada, 41,000. Today: About 1 million in 16 states.

- White-tailed Deer: 1895-About 350,000 south of Canada; extirpated from more than half the states. Today: Approximately 12 million in 48 states.

- Wild Turkey: 1930-Common in only a few southern states, eliminated from most. Today: Restored to 43 states, including establishment in several outside original range of species.

- Fur Seal: 1911-Official census in Pribilof Island showed 215,900. Today: Herd maintained at around 1.5 million under a scientific management program.

- Egrets and Herons: 1910-Several species on the brink of extinction because of slaughter on their nesting grounds by feather collectors to supply the millinery trade. Today: Most species common to abundant over most of the United States.

- Trumpeter Swan: 1935-73 survivors south of Canada on one wildlife refuge. Today: Thriving populations on two national parks and several national wildlife refuges. Removed from endangered status in the late 1960 's.

- Wood Duck: 1915-Greatly reduced in numbers and considered a candidate for early extinction. Today: The most common breeding waterfowl in eastern U.S.A. 
- Sea Otter: 1907-Nearly extinct; a few survivors in Alaska's Aleutian chain and in coastal California. Today: Minimum of 50,000; successfully restored to waters of mainland Alaska, Oregon, Washington, and British Columbia, increasing and extending range in California.

Since 1938, state fish and wildlife agencies have used sportsmen's license fees and special taxes under the Federal Aid in Fish and Wildlife Restoration Acts to:

- Acquire, develop, or manage 2,900 wildlife refuges and management areas totalling nearly 40 million acres. These lands protect vital habitat of a wide range of wildlife and are heavily used by bird watchers, nature students, and other outdoor enthusiasts.

- Construct or restore more than 300 lakes for fish and wildlife with a total surface acreage of 35,000 .

- Acquire or develop more than 3,000 public access areas that open nearly a million otherwise inaccessible acres and 2,000 miles of stream to outdoor recreational use.

- Livetrap and transplant to unoccupied habitat more than 50,000 deer, 16,000 antelope, 2,000 elk, 1,000 mountain sheep, 18,000 fur animals, 20,000 wild turkeys, 22,000 waterfowl, and 130,000 quail.

- Conduct extensive research on wildlife habitat needs, diseases, population trends, predator-prey relationships, and wildlife crop-damage abatement.

- Assist hundreds of thousands of landowners with wildlife habitat improvement projects.

- Conduct public conservation education programs for school teachers and students and promote understanding of wildlife needs and habits through articles and television shows.

- Protect both hunted and nonhunted wildlife by apprehending conservation law violators. Many state conservation law enforcement officers also enforce laws against polluters, whose activities impose serious threats to wildlife and its habitats. But, as in all resource management efforts, public support is essential. 


\section{What You Can Do}

There are many steps the concerned citizen can take to assure the future of America's wildlife.

Those who own land, whether suburban lot, woodlot, farm or ranch, can make improvements that will attract and hold wildlife, often at minimum expense. Your state wildlife agency has publications outlining such improvements. Many state agencies provide on-the-ground technical assistance and inexpensive wildlife food and cover planting stock within the limitations of budget and manpower. Additional information and assistance are available from the Extension Service, U.S. Department of Agriculture, at your state university.

Those who do not own land directly are shareholders in the largest landholdings in the United States. These are the 725 million acres of national forests, parks, wildlife refuges, public domain, and other lands held in trust for the American public by the Federal Government. Even on the national wildlife refuges, program funding has not kept pace with demand. As a citizen shareholder you can insist that Congress and the Administration provide adequate funds to maintain balanced uses of resources and wildlife populations on all public lands.

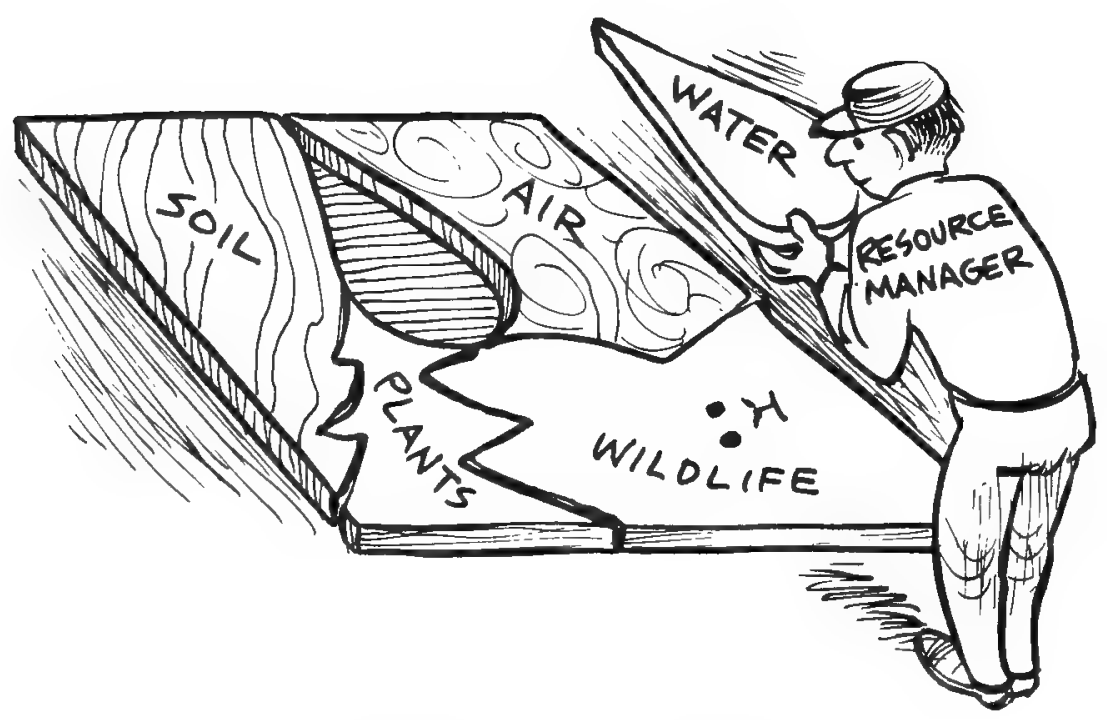

PUTTING IT ALL TOGETHER 
Additionally, all citizens can help wildlife if they:

- Support federal, state, and local efforts to develop land-use planning programs that protect vital wildlife habitat from unnecessary and haphazard development.

- Urge public officials to consider wildlife in all programs affecting land and water developments.

- Insist that agriculture, flood-control, and other publicly subsidized government programs yield broad public benefits in the form of wildlife enhancement.

- Realize that wetlands are not wastelands but essential units of the landscape that have important ecological functions of economic and cultural importance to man.

- Reject simplistic panaceas for maintaining and restoring wildlife based on unscientific emotion.

The perpetuation of wildlife requires the attention of well-trained and experienced specialists. Each state now has a staff of such scientists. See that they have the public support and funds needed to carry out their work in a climate free from political meddling.

America can retain and expand its rich wildlife heritage if it applies scientifically sound facts to the management of all wild species and if its citizens harmonize their activities with the systems of nature.

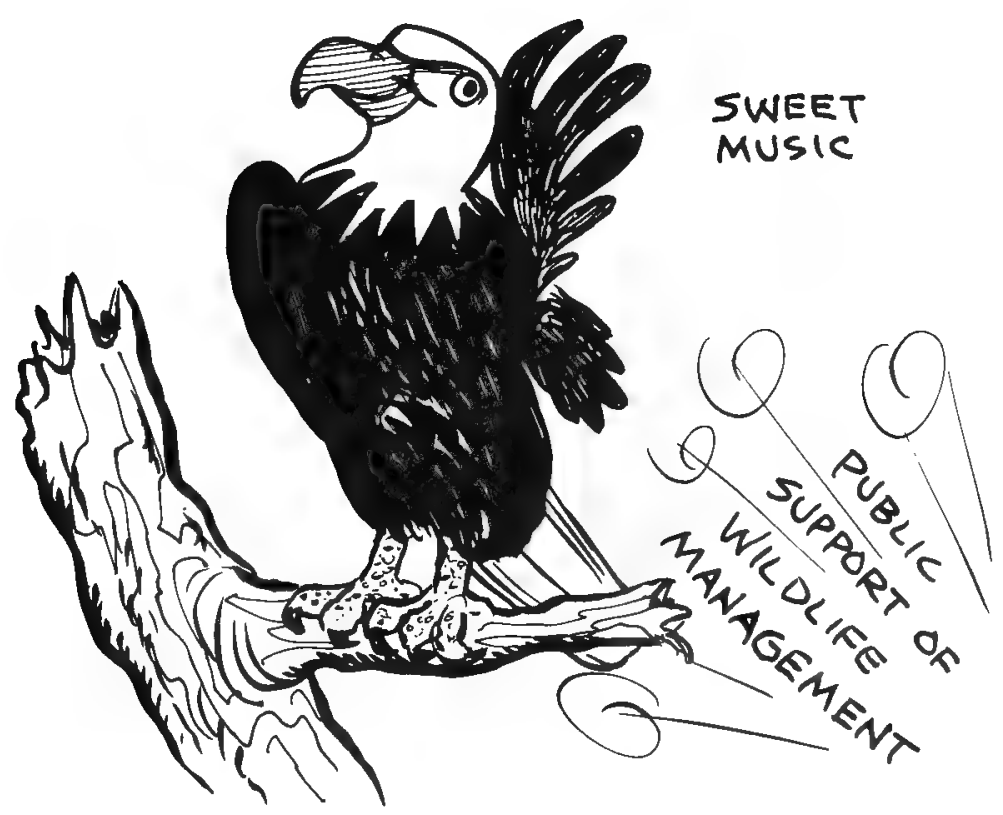


MANAGEMENT BROU BACK

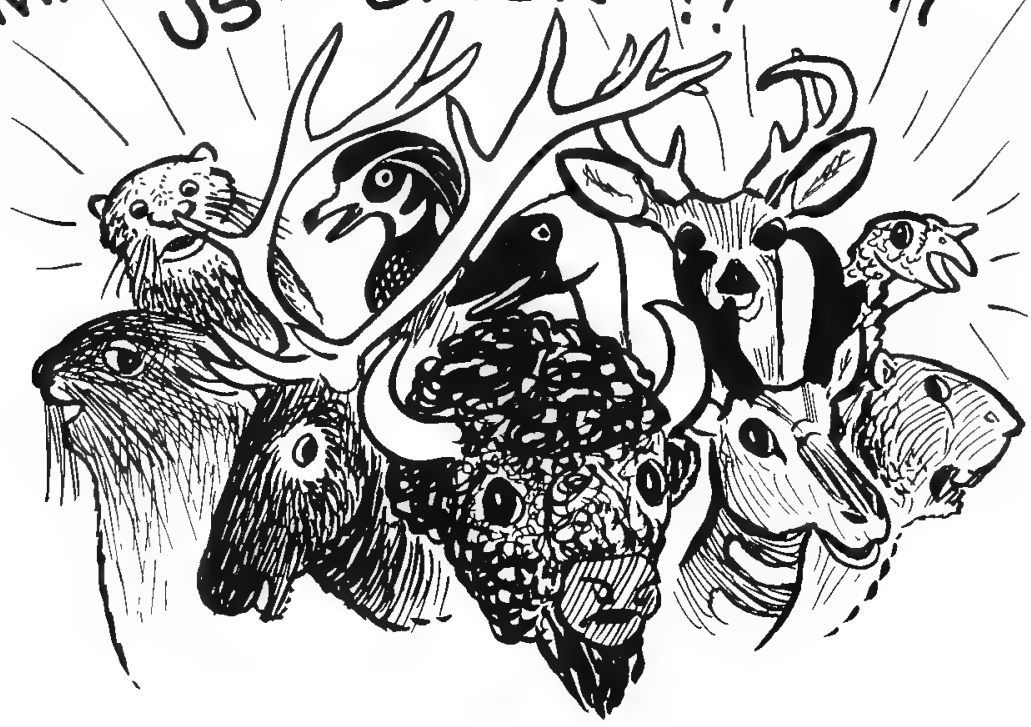




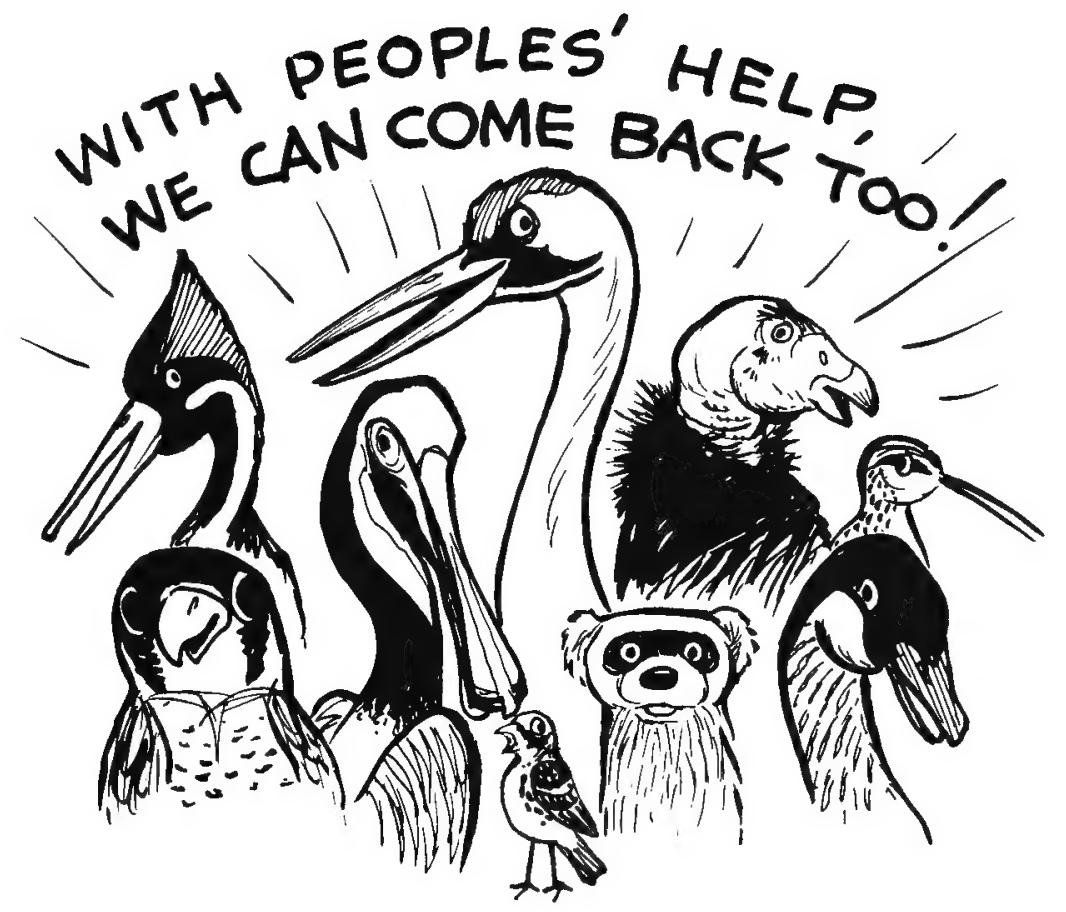




